\title{
BIOAVAILABILITAS TABLET IBUPROFEN PADA PEMBERIAN BERSAMAAN DENGAN EKSTRAK AIR HERBA PEGAGAN (Centella asiatica (L) Urban) PADA KELINCI JANTAN
}

\section{THE EFFECT OF AQUEOUS EXTRACT OF Centella Asiatica (L) Urban TO THE IBUPROFEN TABLET BIOAVAILABILITY IN MALE RABBITS}

\author{
Depprelia Wahyu Sutanti, Iis Wahyuningsih \\ Fakultas Farmasi, Universitas Ahmad Dahlan \\ Jl. Prof. Dr. Soepomo, Janturan, Yogyakarta \\ Email : avinagil@gmail.com.
}

\begin{abstract}
Abstrak
Kecenderungan masyarakat menggunakan obat herbal bersamaan dengan obat sintetik dapat mengakibatkan terjadi interaksi. Penelitian ini dimaksudkan untuk mengetahui pengaruh ekstrak air herba pegagan (Centella asiatica (L) Urban) terhadap bioavailabilitas tablet ibuprofen pada kelinci jantan, dimana ibuprofen dan ekstrak air herba pegagan dimetabolisme oleh enzim CYP450 yang sama dengan mekanisme yang berbeda. Penelitian ini menggunakan rancangan sama subyek dengan design Cross Over menggunakan subyek uji 5 ekor kelinci jantan. Setiap kelinci mendapatkan perlakuan yang sama. Sampel kontrol diberi tablet ibuprofen $400 \mathrm{mg}$, sedangkan sampel perlakuan diberi tablet ibuprofen $400 \mathrm{mg}$ bersamaan dengan ekstrak air herba pegagan dengan konsentrasi $25 \% \mathrm{~b} / \mathrm{v}, 50 \% \mathrm{~b} / \mathrm{v}$ dan $100 \% \mathrm{~b} / \mathrm{v}$. Kemudian diambil darahnya pada jam ke $0 ; 0,5 ; 1 ; 1,5 ; 2 ; 2,5 ; 3 ; 3,5 ; 4 ; 6 ; 8 ; 10$. Konsentrasi ibuprofen dalam plasma diukur menggunakan spektrofotometri. Konsentrasi ibuprofen yang diperoleh digunakan untuk mengukur parameter bioavailabilitas ibuprofen meliputi : $t_{\text {maks }}, C p_{\text {maks }}$, and AUC. Data parameter bioavailabilitas yang dihasilkan dianalisis dengan uji ANOVA satu jalan dengan taraf kepercayaan $95 \%$. Hasil penelitian menunjukkan, penggunaan tablet ibuprofen bersama ekstrak air herba pegagan dapat meningkatkan nilai $C p_{\text {maks }}$ dan AUC, tetapi tidak ada pengaruh terhadap nilai tmaks. Penggunaan ibuprofen bersama ekstrak air herba pegagan $50 \%$ b/v dan 100\%b/v secara signifikan mempengaruhi bioavailabilitas ibuprofen dalam darah.
\end{abstract}

Kata Kunci : bioavailabilitas, ibuprofen, Centella asiatica 


\section{Abstract}

The tendency to use herbal drug simultaneously with synthetic drug may result in an interaction. Based on research, aqueous extract of Centella asiatica (L) Urban contains saponin (asiaticoside and madecassoside) compounds that inhibit CYP450 and is a safe herbal alternative that is used for anti-inflammatory treatment. The aim of this study was to investigate the effect of aqueous extract of Centella asiatica (L) Urban to the ibuprofen tablet bioavailability in male rabbits. Both compounds are metabolized by CYP450 enzymes in the same way with different mechanism. The cross over design with the same subject was used in this study. The samples consisted of $400 \mathrm{mg}$ ibuprofen with $0 \% \mathrm{~b} / \mathrm{v}, 25 \% \mathrm{~b} / \mathrm{v}, 50 \% \mathrm{~b} / \mathrm{v}$ dan $100 \% \mathrm{~b} / \mathrm{v}$ aqueous extract of Centella asiatica $(L)$ Urban respectively. The blood were taken after $0 ; 0,5 ; 1 ; 1,5 ; 2 ; 2,5 ; 3 ; 3,5 ; 4 ; 6 ; 8 ; 10$ hours after samples treatment, then the ibuprofen plasma concentration were determined spectrophotometrically. The results then were used to evaluat the bioavailability parameters: $t_{\text {maks }}, C p_{\text {maks }}$, and AUC and were analyzed using ANOVA test in the same way as well as the 95\% trust standart. The results showed, the use of ibuprofen tablet stimultaneously with aqueous extract of Centella asiatica (L) Urban increased Cpmaks dan AUC, but there were no influence to the tmaks value. The use of ibuprofen tablet stimultaneously with $50 \% \mathrm{~b} / \mathrm{v}$ and $100 \% \mathrm{~b} / \mathrm{v}$ aqueous extract of Centella asiatica (L) Urban had a significant influence to the bioavailability of ibuprofen.

Keywords : bioavailability, ibuprofen, Centella asiatica

\section{PENDAHULUAN}

Jutaan orang menggunakan obat herbal bersamaan dengan obat sintetik tanpa rekomendasi dokter (Gohil and Patel, 2007). Masyarakat umum beranggapan, obat herbal dapat mengurangi efek samping dari obat yang diminum dan dapat meningkatkan efektifitas dari pengobatan (Inamdar et al., 2008). Meskipun dianggap alami, banyak obat herbal yang dapat berinteraksi dengan obat lain menyebabkan efek samping yang berbahaya dan atau mengurangi manfaat dari obat (Gohil and Patel, 2007).

\begin{tabular}{|c|c|}
\hline & $\begin{array}{l}\text { Banyaknya senyawa aktif } \\
\text { farmakologi dalam obat herbal, } \\
\text { berkemungkinan meningkatkan interaksi } \\
\text { yang terjadi. Secara teoritis interaksi } \\
\text { obat herbal dengan obat sintetik lebih } \\
\text { tinggi daripada interaksi dua obat } \\
\text { sintetik karena obat sintetik biasanya } \\
\text { hanya berisi kandungan kimia tunggal } \\
\text { (Izzo, 2004). Penggunaan obat herbal } \\
\text { bersamaan dengan obat sintetik } \\
\text { umumnya tidak terawasi oleh dokter atau } \\
\text { praktisi pengobatan herbal, hal tersebut } \\
\text { dapat mengakibatkan kerugian bagi } \\
\text { pasien, jika obat herbal yang mereka } \\
\text { gunakan dan obat sintetiknya memiliki } \\
\text { interaksi potensial. Interaksi ini }\end{array}$ \\
\hline
\end{tabular}


umumnya tidak diketahui sampai pasien tersebut mengalami sakit atau kejadian serius yang mengancam hidup pasien terjadi (Gohil and Patel, 2007).

Obat herbal dapat berinteraksi dengan obat sintetik melalui interaksi farmakokinetik dan atau farmakodinamik (Rodda et al., 2010). Interaksi farmakokinetik mengakibatkan perubahan absorpsi, distribusi, metabolisme atau ekskresi dari obat sintetik atau obat herbal sehingga dapat mempengaruhi kerja obat secara kuantitatif. Interaksi farmakodinamik mempengaruhi aksi obat secara kualitatif, baik melalui efek meningkatkan (aksi sinergis atau aditif) atau efek antagonis (Gohil and Patel, 2007).

Ibuprofen merupakan derivat dari asam propionat, yang secara luas digunakan sebagai obat antiinflamasi non-steroid, antipiretik dan analgetik (Dewland et al., 2009; Canaparo et al., 2000; Bushra and Aslam, 2010; Rainsford, , 2009). Ibuprofen merupakan obat kelas II berdasarkan Biopharmaceutics Classification System (BCS), menunjukkan permeabilitas yang tinggi dan disolusi rendah (Potthast et al., 2005). Permeabilitas yang tinggi mengakibatkan ibuprofen mudah menembus membran gastrointestinal mendekati hingga $100 \%$. Dengan demikian, disolusi menjadi tahap penentu kecepatan absorpsi (Newa et al., 2008). Obat-obat yang disolusinya rendah menjadi suatu permasalahan dalam industri farmasi karena pada umumnya obat diabsorpsi dari saluran cerna dengan mekanisme difusi pasif sehingga kecepatan disolusi obat akan menentukan

bioavailabilitas

(Blazek-Welsh and Rhodes, 2001).

Seperti halnya ibuprofen, ekstrak air herba pegagan juga memiliki aktifitas sebagai antiinflamasi (Somchit, et al, 2004). Aktivitas antiinflamasi dari ekstrak air herba pegagan dapat dikaitkan dengan adanya glikosida seperti asiaticoside dan madecassoside (George et al., 2009). Assiaticoside merupakan suatu inhibitor aktivitas enzim CYP450 (CYP3A4 dan CYP2C19), dapat menyebabkan interaksi dengan obat yang dimetabolisme oleh enzim termasuk ibuprofen (Winitthana et al., 2009). Enzim CYP450 tidak hanya terdapat di hati tetapi juga banyak terdapat di usus (Obach et al., 2000). Enzim CYP450 berperan dalam proses metabolisme obat, adanya inhibisi enzim CYP450 menyebabkan berkurangnya metabolisme obat (Burnett et al., 2011). Apabila ibuprofen diminum bersama dengan ekstrak air herba pegagan kemungkinan metabolisme ibuprofen yang terjadi di dalam usus berkurang sehingga ibuprofen berada dalam jumlah lebih banyak di usus akibat selanjutnya adalah jumlah ibuprofen yang terabsorpsi akan meningkat.

Berdasarkan pemikiran bahwa masyarakat seringkali mengkonsumsi obat herbal bersamaan dengan obat sintetik, maka memungkinkan terjadinya interaksi antara keduanya. Selama ini masih sedikit informasi tentang interaksi antara obat herbal dan obat sintetik (Gohil and Patel, 2007). Selain itu, sifat dari ibuprofen yang merupakan obat antiinflamasi dimana perubahan pada proses farmakokinetik akan menentukan bioavailabilitas (Blazek-Welsh and 
Rhodes, 2001), maka perlu dilakukan penelitian lebih lanjut mengenai pengaruh ekstrak air herba pegagan Centella asiatica (L) Urban) terhadap bioavailabilitas tablet ibuprofen.

\section{METODE PENELITIAN}

\section{Alat}

Alat-alat yang digunakan dalam penelitian ini adalah sebagai berikut alat-alat gelas (glassware) Pyrex, scapel, pipet mikro, tabung ependrof, vortex (MX-S), sentrifuge (PLC-05), spektrofotometer (PharmaSpec UV-1700 Shimadzu), neraca analitik (ANALITIK AND GR/202), pH meter (PCT-403), Stirer (LMS-1003), ultrasonic $(\mathrm{LC} 30 \mathrm{H})$ dan alat Halogen Moisturizer Analyzer.

\section{Bahan}

Hewan uji yang digunakan adalah kelinci jantan galur lokal dengan berat badan 1,5-1,8 kg. Bahan yang digunakan adalah herba pegagan yang diperoleh dari kaki gunung Ungaran, ibuprofen, tablet ibuprofen generik (Indofarma), kloroform p.a, Natrium Hidroksida p.a.,Asam Klorida (E. Merck) p.a., heparin dan aquades.

\section{Jalannya Penelitian}

1. Determinasi Tanaman dan Pembuatan Ekstrak Air Herba Pegagan (Centella asiatica (L) Urban).

Determinasi tanaman dilakukan di Laboratorium Biologi FMIPA Universitas Ahmad Dahlan untuk memastikan tanaman yang digunakan adalah pegagan serta untuk mengetahui jenisnya. Ekstrak air herba pegagan (Centella asiatica (L) Urban) dibuat dengan cara penyarian dengan maserasi.

\section{Uji Pendahuluan}

a) Penentuan panjang gelombang serapan maksimum ibuprofen dalam plasma darah

Larutan ibuprofen diambil $100 \mu \mathrm{l}$ dimasukkan ke dalam $900 \mu \mathrm{l}$ plasma darah dicampur menggunakan vortex, lalu ditambah 100 $\mu \mathrm{HCl} 1 \mathrm{~N}$ dan dicampur kembali dengan vortex. Selanjutnya diekstraksi dengan $2 \mathrm{ml}$ kloroform sebanyak 3 kali, fase kloroform diambil dan dikumpulkan. Fase kloroform diuapkan sampai kering, lalu ditambahkan $0,1 \mathrm{~N} \mathrm{NaOH} 4 \mathrm{ml}$ dan digunakan untuk mencari panjang gelombang maksimum menggunakan spektrofotometer.

b) Penentuan persamaan kurva baku ibuprofen dalam plasma darah, perolehan kembali dan penentuan stabilitas ibuprofen dalam plasma darah

\section{Penentuan parameter bioavailabilitas ibuprofen dalam darah}

Penelitian ini menggunakan 5 ekor kelinci jantan galur lokal $(\mathrm{n}=5)$ berat badan $1,5-1,8 \mathrm{~kg}$, dengan $\mathrm{CV}$ untuk ke-5 kelinci $<10 \%$ diteliti menggunakan rancangan Cross Over Design (Tabel I) dengan 4 macam perlakuan, seperti tersaji pada tabel I. 
Tabel I. Rancangan Cross Over pada penentuan bioavailabilitas tablet ibuprofen pada pemberian bersama ekstrak air herba pegagan (Centella asiatica (L) Urban).

\begin{tabular}{ccccc}
\hline \multirow{2}{*}{ Kelinci ke } & \multicolumn{4}{c}{ Minggu ke } \\
\cline { 2 - 5 } & I & II & III & IV \\
\hline 1 & $\mathrm{~A}$ & $\mathrm{~B}$ & $\mathrm{C}$ & $\mathrm{D}$ \\
2 & $\mathrm{~B}$ & $\mathrm{C}$ & $\mathrm{D}$ & $\mathrm{A}$ \\
3 & $\mathrm{C}$ & $\mathrm{D}$ & $\mathrm{A}$ & $\mathrm{B}$ \\
4 & $\mathrm{D}$ & $\mathrm{A}$ & $\mathrm{B}$ & $\mathrm{C}$ \\
5 & $\mathrm{~A}$ & $\mathrm{~B}$ & $\mathrm{C}$ & $\mathrm{D}$ \\
\hline
\end{tabular}

$\mathrm{A}=$ Tablet ibuprofen $400 \mathrm{mg}$ (kontrol), $\mathrm{B}=$ Pemberian tablet ibuprofen bersamaan dengan $5 \mathrm{ml}$ ekstrak air herba pegagan kadar $25 \% \mathrm{~b} / \mathrm{v}, \mathrm{C}=$ Pemberian tablet ibuprofen bersamaan dengan $5 \mathrm{ml}$ ekstrak air herba pegagan kadar $50 \% \mathrm{~b} / \mathrm{v}, \mathrm{D}=$ Pemberian tablet ibuprofen bersamaan dengan $5 \mathrm{ml}$ ekstrak air herba pegagan kadar $100 \% \mathrm{~b} / \mathrm{v}$

Kadar ibuprofen dalam darah ditetapkan seperti point 3a, lalu kadarnya ditentukan menggunakan garis regresi linear dari kurva baku. Parameter bioavailabilitas meliputi $t_{\text {maks }}, C p_{\text {maks }}$ yang diperoleh dari grafik dan AUC yang diperoleh dengan metode trapezoid.

\section{Analisis Data}

Data yang diperoleh dianalisis secara statistik dengan uji homogenitas varian (uji Levene) dan uji terdistribusi normal (Kolmogorof Smirnov), dilanjutkan dengan analisis varian satu jalan (ANOVA) dan Post Hoc Test (LSD) untuk mengetahui perbedaan antar perlakuan dengan taraf kepercayaan $95 \%$ atau uji Kruskal Walls dilanjutkan dengan uji Mann Whitney.

\section{HASIL DAN PEMBAHASAN}

\section{Determinasi Tanaman}

Hasil determinasi tanaman pegagan berpedoman pada buku Flora of
Java (Backer, 1965) adalah sebagai berikut:

1b-2b-3b-12b-13b-14b-17b-18b19b-20b-21b-22b-23b-24b-25b-26b-27 b-28b-29b-30b-31b-32b-74a-75b-76a-7 7b-104b-106b-107a-108b-109a-110b-1 15a-116b-117b-118b Apiaceae 1b-18b-19b-20b Centela

\section{Centela asiatica (L) Urban}

Berdasarkan hasil determinasi tersebut dapat diperoleh kepastian bahwa tanaman yang digunakan dalam penelitian ini benar-benar Centella asiatica (L) Urban.

\section{Panjang Gelombang Serapan Maksimum Ibuprofen dalam Plasma Darah}

Pada penelitian ini diperoleh panjang gelombang serapan maksimum dari larutan standar ibuprofen $195 \mu \mathrm{g} / \mathrm{ml}$ dalam plasma darah adalah $273,0 \mathrm{~nm}$ dengan absorbansi 0,402, seperti nampak pada gambar 1 . 


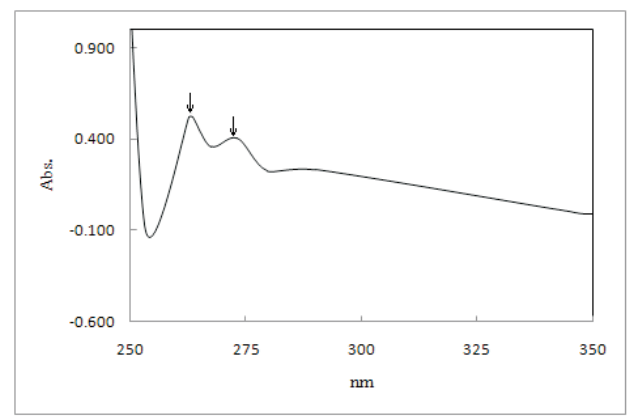

Gambar 1. Spektra panjang gelombang maksimal ibuprofen dalam plasma darah

\section{Persamaan Kurva Baku Ibuprofen dalam Plasma Darah}

Pada penelitian ini, diperoleh persamaan regresi kurva baku sebagai berikut: $\mathrm{Y}=0,00257 \mathrm{X}+0,00563$, dimana $\mathrm{X}=\operatorname{kadar}(\mu \mathrm{g} / \mathrm{ml})$ dan $\mathrm{Y}=$ absorbansi dengan harga koefisien korelasi, $\mathrm{r}=0,999$ sedangkan $\mathrm{r}$ tabel $=$ 0,878 ( $\mathrm{n}=5$ dan $\mathrm{P}=95 \%$ ). Harga koefisien korelasi dari kurva baku yang diperoleh lebih besar dari $r$ tabel sehingga dapat disimpulkan bahwa persamaan garis yang diperoleh menunjukkan adanya hubungan yang signifikan antara konsentrasi larutan standar ibuprofen dengan absorbansi. Persamaan ini digunakan untuk menghitung kadar ibuprofen.

\section{Perolehan Kembali}

Penentuan harga perolehan kembali bertujuan untuk mengetahui ketepatan suatu metode analisis. Ketepatan adalah kedekatan hasil yang diperoleh dengan harga yang sebenarnya. Persyaratan perolehan kembali metode analisis adalah 90-110\% (acuan). Pada penelitian harga perolehan kembali yang dihasilkan memenuhi syarat akurasi, hal ini berarti bahwa hasil yang teramati dalam penetapan kadar pada penelitian ini mendekati harga sebenarnya. Data selengkapnya dapat dilihat pada tabel II.

\section{Stabilitas Ibuprofen}

Uji stabilitas ini dilakukan untuk memperkirakan kestabilan ibuprofen

Tabel II. Harga perolehan kembali ibuprofen

\begin{tabular}{ccccc}
\hline No & $\begin{array}{c}\text { Konsentrasi } \\
(\boldsymbol{\mu} \mathbf{g} / \mathbf{m l})\end{array}$ & Absorbansi & $\begin{array}{c}\text { Absorbansi hasil } \\
\text { ekstraksi dalam } \\
\text { plasma }\end{array}$ & $\begin{array}{c}\text { Perolehan } \\
\text { kembali } \\
\text { (\% recovery) }\end{array}$ \\
\hline 1 & 75 & 0,300 & 0,257 & 85,667 \\
& & & 0,295 & 98,333 \\
& Mean \pm SD & & 0,287 & 95,667 \\
2 & 195 & 0,564 & $0,279 \pm 0,020$ & $93,222 \pm 6,678$ \\
& & & 0,509 & 90,248 \\
& & & 0,587 & 104,078 \\
3 & \multirow{2}{*}{0,851} & $0,279 \pm 0,020$ & $94,740 \pm 8,089$ \\
& 315 & & 0,834 & 98,002 \\
& & & 0,838 & 98,472 \\
& Mean $\pm \mathrm{SD}$ & & $0,843 \pm 0,013$ & 100,823 \\
& & & & $99,099 \pm 1,511$ \\
\hline
\end{tabular}


dalam keadaan kering sebelum penambahan $4 \mathrm{ml} \mathrm{NaOH} 0,1 \mathrm{~N}$ apabila cuplikan tidak segera dibaca absorbansinya. Stabilitas ini dinyatakan dengan persen degradasi terhadap kadar awal $\mathrm{t}=1$ jam dan hasilnya dapat dilihat pada tabel III.

Tabel III menunjukkan bahwa ibuprofen dalam keadaan kering sebelum penambahan $4 \mathrm{ml} \mathrm{NaOH} 0,1 \mathrm{~N}$ relatif lebih stabil apabila disimpan di dalam lemari es. Penyimpanan dalam lemari es akan menurunkan nilai degradasi ibuprofen yang tidak bisa langsung dibaca absorbansinya.

\section{Penentuan Kadar Ibuprofen pada Masing-masing Perlakuan}

Hasil penetapan kadar ibuprofen dalam plasma darah pada masing-masing perlakuan disajikan dalam gambar 1 .

Kadar ibuprofen pada perlakuan kontrol mulai naik pada jam ke-2 dengan kadar puncak dalam plasma darah sebesar $165,90 \mu \mathrm{g} / \mathrm{ml}$. Kadar yang diperoleh lebih kecil dibandingkan perlakuan yang lain. Hal ini kemungkinan karena belum adanya interaksi antara ibuprofen dengan ekstrak air herba pegagan, sehingga kecepatan absorpsi obat tidak terganggu. Kadar obat dalam darah akan naik bila kecepatan absorpsi lebih besar daripada kecepatan eliminasi (acuan). Setelah obat yang siap diabsorpsi tinggal sedikit maka absorpsi akan menjadi lambat sehingga kadar obat dalam darah akan menurun.

Salah satu manfaat dari ekstrak air herba pegagan adalah memberikan efek antiinflamasi Winitthana et al., 2009; (George, 2009) sehingga dilakukan perlakuan ibuprofen bersama dengan ekstrak air herba pegagan untuk mengetahui perubahan parameter bioavailabilitas dari ibuprofen. Tampak gambar 1, bahwa pemberian ibuprofen bersama dengan ekstrak air herba pegagan baik kadar $25 \% \mathrm{~b} / \mathrm{v}, 50 \% \mathrm{~b} / \mathrm{v}$ maupun $100 \% \mathrm{~b} / \mathrm{v}$ dapat berpengaruh pada profil obat, pada umumnya kadar obat dalam darah mengalami peningkatan seiring meningkatnya konsentrasi ekstrak air herba pegagan yang diberikan, tetapi waktu untuk mendapatkan kadar puncak pada masing-masing perlakuan hampir sama.

Perlakuan B merupakan pemberian tablet ibuprofen bersama ekstrak air herba pegagan $25 \% \mathrm{~b} / \mathrm{v}$, kadar puncak yang diperoleh yaitu sebesar 185,51 $\mu \mathrm{g} / \mathrm{ml}$ pada jam ke-2. Perlakuan C merupakan pemberian bersama ekstrak air herba pegagan $50 \% \mathrm{~b} / \mathrm{v}$, kadar puncak yang diperoleh yaitu sebesar 242,48 $\mu \mathrm{g} / \mathrm{ml}$ pada jam ke-2. Perlakuan D

Tabel III. Harga persen degradasi ibuprofen terhadap kadar awal pada variasi waktu dan suhu

\begin{tabular}{cccc}
\hline Kondisi suhu & $\begin{array}{c}\text { Lama pengujian } \\
\text { (jam) }\end{array}$ & Absorbansi & \% degradasi \\
\hline & 1 & 0,380 & 0 \\
Suhu kamar ( \pm 25 OC) & 12 & 0,235 & 38,158 \\
Freezer (-20 OC) & 24 & 0,161 & 57,632 \\
\hline
\end{tabular}


merupakan pemberian bersama ekstrak air herba pegagan $100 \% \mathrm{~b} / \mathrm{v}$, kadar puncak yang diperoleh yaitu 286,13 $\mu \mathrm{g} / \mathrm{ml}$ pada jam ke-2. Pada setiap perlakuan, mulai terjadi peningkatan kadar ibuprofen dalam plasma darah pada jam ke-0,5 dan mencapai puncak pada jam ke-2, lalu terjadi penurunan kadar ibuprofen dalam plasma darah setelah jam ke-2.

\section{Penentuan parameter bioavailabilitas ibuprofen}

Parameter bioavailabilitas meliputi $\mathrm{t}_{\text {maks }}$, $\mathrm{Cp}_{\text {maks }}$ dan Area Under Curve (AUC ${ }^{0-8}$ ) yang ditentukan dengan menggunakan metode trapezoid (Patel et al., 2010) dari kadar rata-rata yang diperoleh (acuan), karena hasil yang didapat sangat variatif sehingga peneliti kesulitan dalam menganalisis data, maka $\mathrm{t}_{\text {maks }}$ dan $C \mathrm{p}_{\text {maks }}$ diperoleh dari rata-rata setiap perlakuan dengan melihat kurva. Hasil selengkapnya dapat dilihat pada tabel IV.

Hasil percobaan memperlihatkan harga $t_{\text {maks }}$ ibuprofen pada kontrol dan semua perlakuan hampir sama. Uji Kruskal Walls menghasilkan nilai signifikansi untuk harga $t_{\text {maks }}$ lebih besar dari 0,05, maka dapat diambil kesimpulan bahwa tidak ada perbedaan $t_{\text {maks }}$ pada tiap perlakuan.

Pemberian tablet ibuprofen bersama ekstrak air herba pegagan mengalami peningkatan nilai $\mathrm{Cp}_{\text {maks }}$ bila dibandingkan dengan kontrol. Nilai $\mathrm{C} \mathrm{p}_{\text {maks }}$ ibuprofen terbesar diperoleh dari perlakuan pemberian tablet ibuprofen bersama ekstrak air herba pegagan 100 $\% \mathrm{~b} / \mathrm{v}$. Uji Post Hoc Test (LSD) membuktikan tidak ada perbedaan yang signifikan antara perlakuan kontrol dan pemberian bersama tablet ibuprofen dengan ekstrak air herba pegagan 25 $\% \mathrm{~b} / \mathrm{v}$ tetapi ada perbedaan yang signifikan antara perlakuan kontrol dan pemberian bersama dengan ekstrak air herba pegagan $50 \% \mathrm{~b} / \mathrm{v}$ dan $100 \% \mathrm{~b} / \mathrm{v}$. Hal tersebut menunjukkan adanya perlakuan peningkatan konsentrasi ekstrak air herba pegagan, memungkinkan terdapatnya lebih banyak zat aktif. Salah satu zat aktif dari ekstrak air herba pegagan yaitu saponin jenis asiaticoside dan madecassoside yang memiliki aktifitas sebagai antiinflamasi ((Zheng dan Qin, 2007; James and Dubery, 2009). Assiaticoside merupakan suatu inhibitor aktivitas enzim CYP450 (CYP3A4 dan CYP2C19) (Winitthana et al. 2009). Enzim CYP450 banyak terdapat di dalam hati maupun usus (acuan). Enzim ini berperan di dalam proses metabolisme. Adanya inhibisi enzim CYP450 menyebabkan berkurangnya metabolisme obat baik metabolisme yang terjadi di hati maupun di usus. Apabila ibuprofen diminum bersama dengan ekstrak air herba pegagan kemungkinan metabolisme ibuprofen yang terjadi di dalam usus berkurang sehingga terjadi peningkatan ibuprofen yang berada di usus, akibat selanjutnya akan terjadi peningkatan ibuprofen yang terabsorpsi.

Nilai AUC terkecil diperoleh dari perlakuan kontrol, yaitu 1161,78 $\mu \mathrm{g} / \mathrm{ml}$.jam dan nilai AUC terbesar diperoleh dari perlakuan pemberian bersama ekstrak air herba pegagan 100 $\%$ b/v, yaitu 1737,04 $\mu \mathrm{g} / \mathrm{ml}$. Nilai AUC ibuprofen meningkat seiring dengan peningkatan konsentrasi ekstrak air herba pegagan karena kadar zat aktif 
yang dikandung juga lebih banyak. Akan tetapi, nilai AUC perlakuan pemberian bersama ekstrak air herba pegagan $50 \% \mathrm{~b} / \mathrm{v}$ lebih kecil dibanding perlakuan pemberian $100 \% \mathrm{~b} / \mathrm{v}$, hal ini kemungkinan adanya variasi biologis dari setiap kelinci. Uji Mann Whitney menunjukkan bahwa tidak ada perbedaan yang signifikan antara perlakuan kontrol dan pemberian bersama tablet ibuprofen dengan ekstrak air herba pegagan 25 $\% \mathrm{~b} / \mathrm{v}$ dan $50 \% \mathrm{~b} / \mathrm{v}$, tetapi ada perbedaan yang signifikan antara kontrol dan pemberian bersama dengan ekstrak air herba pegagan $100 \% \mathrm{~b} / \mathrm{v}$.
AUC dan $\mathrm{Cp}_{\text {maks }}$ serta terjadi perubahan pada nilai $t_{\text {maks. }}$. Hasil yang tidak sejalan ini, kemungkinan disebabkan adanya perbedaan senyawa yang terkandung di dalam air perasan temulawak, perbedaan dosis ibuprofen yang diberikan dan perbedaan metode penelitian yang digunakan, serta perbedaan subyek penelitian. Penelitian Priyanto, dkk menggunakan tikus sebagai subyek penelitian sedangkan dalam penelitian ini menggunakan subyek uji kelinci.

Penelitian yang dilakukan oleh Doshi dan Deshpande (2007) dengan subyek uji kelinci menyebutkan bahwa

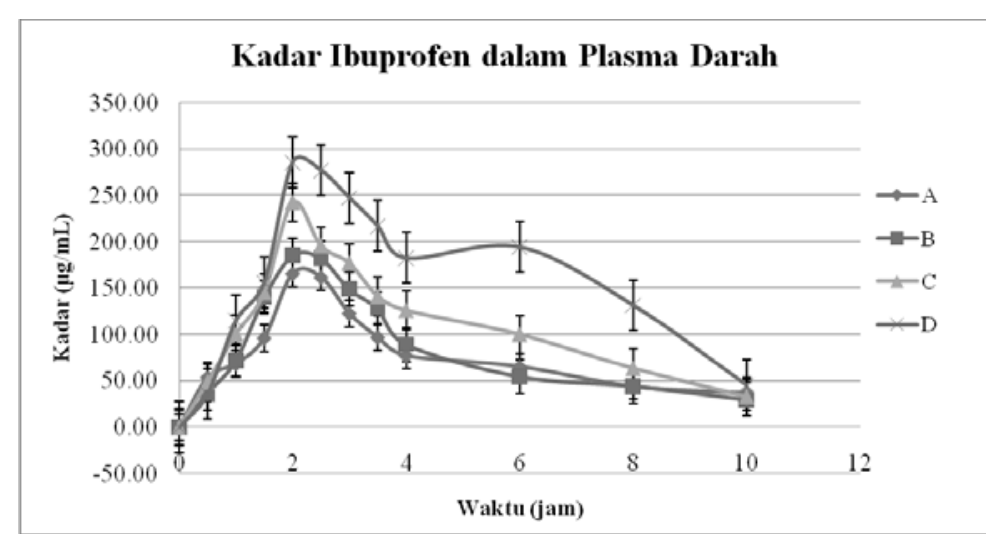

Gambar 2 . Kurva kadar ibuprofen dalam plasma sebagai fungsi waktu, pada masing-masing perlakuan kelinci jantan secara oral dengan dosis $400 \mathrm{mg}$

Hasil penelitian ini sama dengan hasil yang diperoleh Priyanto, dkk (2011) bahwa tablet ibuprofen yang diberikan bersamaan dengan air perasan temulawak dapat mempengaruhi bioavailabilitas ibuprofen dalam darah. Tetapi pengaruhnya berbeda, ekstrak air pegagan cenderung mengakibatkan AUC dan $C p_{\text {maks }}$ ibuprofen meningkat sedangkan air perasan temulawak mengakibatkan penurunan parameter harga $t_{\text {maks }}$ ibuprofen dalam plasma tercapai pada jam ke-1,5 dengan C p $_{\text {maks }}$ ibuprofen sebesar 30,91 $\mu \mathrm{g} / \mathrm{ml}$. Perbedaan ini kemungkinan disebabkan perbedaan dosis yang diberikan. Selain itu metode pengukuran yang digunakan berbeda, pengukuran dengan menggunakan kromatografi cair kinerja tinggi akan memberikan hasil yang lebih baik.

Indeks terapi ibuprofen dalam darah pada manusia yaitu pada kadar 
Tabel IV. Harga purata parameter bioavailabilitas ibuprofen pada kelinci jantan

\begin{tabular}{lcccc}
\hline & \multicolumn{4}{c}{ Perlakuan } \\
\cline { 2 - 5 } Parameter & $\mathbf{A}$ & $\mathbf{B}$ & $\mathbf{C}$ & $\mathbf{D}$ \\
& Mean \pm SE & Mean \pm SE & Mean \pm SE & Mean \pm SE \\
\hline $\mathrm{Cp}_{\text {maks }}(\mu \mathrm{g} / \mathrm{ml})$ & $185,902 \pm$ & $201,466 \pm 8,008^{*}$ & $248,316 \pm 2,019 \#$ & $287,692 \pm$ \\
& 8,483 & & & $7,722 \#$ \\
$\mathrm{t}_{\text {maks }}(\mathrm{jam})$ & $2,2 \pm 0,122$ & $2,2 \pm 0,122^{*}$ & $1,9 \pm 0,100^{*}$ & $2,1 \pm 0,100^{*}$ \\
$\mathrm{AUC}^{0-8}$ & 1161,78 & 1390,30 & 1189,59 & 1737,04 \\
$(\mu \mathrm{g} / \mathrm{ml} . \mathrm{jam})$ & $\pm 166,43$ & $\pm 526,57^{*}$ & $\pm 94,680^{*}$ & $\pm 97,613 \#$ \\
\hline
\end{tabular}

Keterangan : * tidak ada perbedaan bermakna dengan perlakuan A $(\mathrm{p}>0,05)$

\# ada perbedaan bermakna dengan perlakuan A $(\mathrm{p}<0,05)$

$10-50 \mu \mathrm{g} / \mathrm{ml}$ dan kadar toksik $>100$ $\mu \mathrm{g} / \mathrm{ml}$ (Davies, 1998), sedangkan pada penelitian ini kadar maksimum ibuprofen dalam darah pada berbagai perlakuan begitu bervariasi, kadar maksimum ibuprofen pada keempat kelompok perlakuan berada di luar indeks terapi ibuprofen dan bahkan melebihi kadar toksik dari ibuprofen, untuk kontrol sebesar $185,902 \mu \mathrm{g} / \mathrm{ml}$, perlakuan pemberian tablet ibuprofen bersamaan dengan ekstrak air herba pegagan $25 \% \mathrm{~b} / \mathrm{v}$ sebesar $201,466 \mu \mathrm{g} / \mathrm{ml}$, perlakuan pemberian tablet ibuprofen bersamaan dengan ekstrak air herba pegagan $50 \% \mathrm{~b} / \mathrm{v}$ sebesar $248,316 \mu \mathrm{g} / \mathrm{ml}$, dan perlakuan pemberian tablet ibuprofen bersamaan dengan ekstrak air herba pegagan $100 \% \mathrm{~b} / \mathrm{v}$ sebesar $287,692 \mu \mathrm{g} / \mathrm{ml}$, hal ini terjadi tentunya karena penelitian ini menggunakan subyek penelitian yang berbeda, yaitu menggunakan kelinci dimana memiliki volume distribusi yang lebih kecil daripada manusia, sehingga kadar ibuprofen dalam darah pun menjadi tinggi berada di luar indeks terapi dan bahkan melebihi kadar toksiknya dalam darah, faktor lain pun ikut menentukan hasil penetapan kadar ibuprofen dalam darah, seperti metode pengukuran yang digunakan dan formulasi dalam sediaan (Hetal et al., 2010).

\section{KESIMPULAN}

1. Penggunaan tablet ibuprofen bersama ekstrak air herba pegagan dapat meningkatkan nilai $\mathrm{Cp}_{\text {maks }}$ dan $\mathrm{AUC}$, tetapi tidak ada pengaruh terhadap nilai $t_{\text {maks }}$.

2. Penggunaan ibuprofen bersama ekstrak air herba pegagan $50 \% \mathrm{~b} / \mathrm{v}$ dan $100 \% \mathrm{~b} / \mathrm{v}$ secara signifikan mempengaruhi bioavailabilitas ibuprofen dalam darah.

\section{DAFTAR PUSTAKA}

Backer, and Van den Brink, 1965, Flora of Java, vol. II, N.V.P. Noordhoff, Groningen, The Netherlands, 172-173. 
Blazek-Welsh and Rhodes., 2001, Maltodextrin Based Proniosomes, AAPS PharmSci, 3(1):1.

Burnett, Pillai, Bitto, Squadrito, and Levy, 2011, Evaluation of CYP450 Inhibitory Effects and Steady State Pharmacokinrtics of Genistein in Combination With Cholecalciferol and Citrated Zinc Bisglycinate in Postmenopausal Women, International Journal of Women's Health, 3: 139-150.

Bushra, and Aslam, 2010, Clinical Pharmacology of Ibuprofen, Oman Medical Journal, 25(3): 155-161.

Canaparo, Muntoni, Zara, Pepa, Berno, Costa, and Eandi, 2000, Determination of Ibuprofen in Human Plasma by High-Performance Liquid Chromatography: Validation and Application in Pharmacokinetic Study, Biomed.Chromatogr., 14: 219-226.

Davies, 1998, Clinical pharmacokinetics of ibuprofen, The first 30 years, Clinical Pharmacokinetic, 34:101-154.

Dewland, Reader, Berry, 2009, Bioavailability of Ibuprofen Following Oral Administration of Standard Ibuprofen, Sodium Ibuprofen or Ibuprofen Acid Incorporating Poloxamer in Healthy Volunteers, $B M C$ Clinical Pharmacology, 9(19): 1-10.

Doshi, and Deshpande, 2007, In Vivo Pharmacokinetic of Prodrug of Ibuprofen, Indian Journal of
Pharmaceutical Sciences, 69 (6): 824-827.

George, Joseph, Ramaswamy, 2009, Anti Allergic, Anti Pruritic, and Anti Inflammatory Activities of Centella Asiatica Extracts, Afr. $J$. Trad., 6(4): 554-559.

Gohil, and Patel, 2007, Herb-Drug Interactions, Indian Journal of Pharmacology, 39(3):129-139.

Hetal, Bindesh, and Sneha; 2010, Technique for Oral Bioavailability Enhancement of Drugs, International Journal of Pharmaceutical Sciences Review and Research, 4(3): 203-223.

Inamdar, Edalat, Kotwal, Pawar, 2008, Herbal Drugs in Milieu of Modern Drugs, International Journal of Green Pharmacy, 2(1):2-8.

Izzo, 2004, Herb-Drug Interactions, Fundamental \& Clinical Pharmacology, 19: 1-16.

James, and Dubery, 2009, Pentacyclic Triterpenoids from the Medicinal Herb Centella asiatica (L.) Urban, Molecules, 14: 3922-3941.

Newa, Bhandari, Kim, Im, Kim, Yoo, Woo, Choi, and Yong, 2008, Enhancement of Solubility, Dissolution and Bioavailability of Ibuprofen in Solid Dispersion Systems, Chem. Pharm. Bull. 56(4): 569-574.

Obach, Zhang, Dunbar, Kaminsky, 2000, Metabolic Characterization of the Major Human Small Intestinal Cytochrome P450S, Aspet Journal, 29(3): 347-352. 
Patel, Aneja, Tiwari, 2010, Bioavailability and Bioequivalence Trials and Its Necessity, International Journal of Pharmacy and Pharmaceutical Sciences, 2(3): 1-8.

Potthast, Dressman, Junginger, Midha, Oeser, Shah, Vogelpoel, Barends, 2005, Immediate Release Solid Oral Dosage Forms: Ibuprofen, $J$ Pharm Sci, 94:2121-2131.

Priyanto, Supandi, Kristantinah, 2011, Pengaruh Pemberian Perasan Temulawak (Curcuma xanthorrhiza) Terhadap Parameter AUC dan $\mathrm{C}_{\text {maks }}$ Ibuprofen yang Diberikan Secara Oral pada Tikus Jantan Galur Wistar,

http://www.foxitsoftware.com (diakses tanggal 30 September 2011).

Rainsford, 2009, Ibuprofen: Pharmacology, Efficacy and
Safety, Infiammopharmacol, 17: 275-342.

Rodda, Molmoori, Samala, Banala, Ciddi, 2010, An Insight into Herb

- Drug Interactions, International Journal of Pharmaceutical Sciences and Nanotechnology, 2(4): 689-706.

Somchit, Sulaiman, Zuraini, Samsuddin, Somchit, Israf, Moin, 2004, Antinociceptive and Antiinflammatory Effects of Centella Asiatica, Indian $J$. Pharmacol, 36(6):377-380.

Winitthana, Tantisira, Niwattisaiwong, Lawanprasert, 2009, Effects of Asiaticoside and Madecassoside on Human Cytochrome P450, Thai J. Pharmacol, 31(1):111.

Zheng, Qin, 2007, Chemical Components of Centella Asiatica and Their Bioactivities, J Chin Integr Med, 5(3): 348-351. 